\title{
Groundwater surface water interactions and the role of phreatophytes in identifying recharge zones
}

\author{
T. S. Ahring ${ }^{1, *}$ and D. R. Steward ${ }^{1}$ \\ ${ }^{1}$ Kansas State University, Department of Civil Engineering, 2118 Fiedler Hall, Manhattan, Kansas, 66506-5000, USA \\ *now at: Southwest Kansas Groundwater Management District \#3, 2009 East Spruce Street, Garden City, \\ Kansas, 67846, USA
}

Correspondence to: D. R. Steward (steward@ksu.edu)

Received: 21 May 2012 - Published in Hydrol. Earth Syst. Sci. Discuss.: 14 June 2012

Revised: 8 October 2012 - Accepted: 25 October 2012 - Published: 9 November 2012

\begin{abstract}
Groundwater and surface water interactions within riparian corridors impact the distribution of phreatophytes that tap into groundwater stores. The changes in canopy area of phreatophytes over time is related to changes in depth to groundwater, distance from a stream or river, and hydrologic soil group. Remote sensing was used to determine the location of trees with pre-development and post-development aerial photography over the Ogallala Aquifer in the central plains of the United States. It was found that once the depth to groundwater becomes greater than about $3 \mathrm{~m}$, tree populations decrease as depth to water increases. This subsequently limited the extent of phreatophytes to within $700 \mathrm{~m}$ of the river. It was also found that phreatophytes have a higher likelihood of growing on hydrologic soil groups with higher saturated hydraulic conductivity. Phreatophytes exist along portions of the Arkansas River corridor where significant decreases in groundwater occurred as long as alluvium exists to create perched conditions where trees survive dry periods. Significant decreases (more that $50 \%$ ) in canopy cover exists along river segments where groundwater declined by more than $10 \mathrm{~m}$, indicating areas with good hydraulic connectivity between surface water and groundwater. Thus, interpretation of changes in phreatophyte distribution using historical and recent aerial photography is important in delineating zones of enhanced recharge where aquifers might be effectively recharged through diversion of surface water runoff.
\end{abstract}

\section{Introduction}

Groundwater is often tapped in the semiarid grasslands of the world where limited precipitation and water demands often exceed natural recharge rates. A case study for aquifer depletion is the Ogallala Aquifer, which supports $30 \%$ of the irrigated agriculture in the United States. While groundwater provides a foundation to sustain agriculture, municipalities, and industry through dry periods, long-term sustainability challenges exist due to aquifer depletion. The species and composition of riparian habitat along the rivers and streams that overlie the Ogallala Aquifer in Western Kansas have changed across pre-development to post-development conditions. Since most riparian tree species use high quantities of water, alteration of location and density may serve as an indicator of changes in local water table. This study uses changes in riparian trees to identify zones of groundwater/surface water interactions.

Phreatophytes are plants capable of directly tapping into the capillary fringe above groundwater stores and hydraulically redistributing water (Amenu and Kumar, 2008). In Western Kansas, the two dominant phreatophyte tree species are cottonwood (populous deltoids) and salt cedar (Tamarisk). Cottonwood trees are typically found in flood plains because they require floods to germinate (Nagler et al., 2005). Cottonwoods have a maximum rooting depth of $2.6 \mathrm{~m}$ (Canadell et al., 1996), their roots do not penetrate soils with low hydraulic conductivity (Law et al., 2000; Cooper et al., 2003), and they consume $0.62 \mathrm{~m}^{3}$ of groundwater per day (Butler Jr. et al., 2007). Water use by tamarisk has been 
estimated to be as high as $0.76 \mathrm{~m}^{3} \mathrm{day}^{-1}$ for a single tree (Hoddenbach, 1987), though subsequent studies have shown that actual water use per canopy area by tamarisk is comparable to water use by cottonwoods (Owens and Moore, 2007). Tamarisk maintains a high level of ET even during periods of stress, and it is capable of tapping groundwater to depths below $10 \mathrm{~m}$ (Busch et al., 1992; Cleverly et al., 2006). Tamarisk also has the property that it is highly resistant to soil salinity and accumulates salinity in its vicinity (Shafroth et al., 2005).

The central plains region in the United States of America was largely devoid of trees prior to the mid-1800s due to grazing by local wildlife, natural prairie fires, and winter fuel burning during to the rise of the horse culture (West and Ruark, 2004). Phreatophyte trees became established as prairie fires and native grazing ceased due to conversion of grasslands to agriculture. Irrigated agriculture began in Kansas during the late 1800 s using ditch irrigation and windpowered pumps. While centrifugal pumps were introduced in the 1890s, these pumps required a water table no deeper than 20 feet to be effective. It was not until the 1940s that technology advanced far enough for pumping the deep Ogallala Aquifer to become economically feasible, and after weathering the Dust Bowl of the 1930s many farmers turned to irrigated agriculture (Opie, 2000). Groundwater resources were appropriated through the 1980s to beyond sustainable rates of natural recharge; this has lead to substantial groundwater table declines and decreased streamflows in the Arkansas and Cimarron Rivers in Western Kansas. We are studying how these declines have caused a redistribution of phreatophyte trees, reflecting the availability of a local water supply.

Previous studies have examined changes in groundwater stores, the balance of groundwater recharge and pumping, and sustaining the usable lifetime of the Ogallala Aquifer. The rate of recharge to the Ogallala Aquifer is low and beyond sustainable irrigation development in many regions such as our study site (Sophocleous, 2005), although significantly higher recharge occurs in other locations of the Ogallala Aquifer, such as the Sand Hills of Nebraska (Szilagyi et al., 2012). Recharge is limited through terrestrial ecosystems due to thick loess soils holding water, which enables dryland farming practices to store water in the soils during fallow years and grow crops in subsequent seasons (Devlin and Sophocleous, 2005). Steward and Ahring (2009) studied the paths of water particles captured by cottonwoods near Larned, Kansas and demonstrated how fields of trees are capable of siphoning groundwater stores from upper regions of the aquifer.

Brunke and Gonser (1997) reviewed the connectivity between river and groundwater, viewing them as linked components of the hydrologic ecosystem. Beneath any stream or river, a hyporheic zone exists defined as "a saturated, subterranean matrix of interstitial spaces characterized by permanent darkness, low current velocities, and high substrate stability." The exchange process between groundwater and surface water is influenced by the geological and anthropogenic genesis of the catchment area, hydrology, climate, and geomorphology. Rivers with lower elevation than groundwater have baseflow from groundwater to surface water that sustains rivers during dry seasons; rivers with higher elevation serve as areas of enhanced infiltration to groundwater. The direction and rate of flow in this exchange is dependent on hydraulic head gradient and sediment properties (Brunke and Gonser, 1997). This process is temporal as precipitation provides runoff and increased interflow, leading to higher surface water elevation that may infiltrate to groundwater. Excessive pumping of an aquifer can lead to colmation, which reduces the function of the hyporheic zone and makes infiltration less likely even with the presence of streamflow. Such reductions of infiltration cause the water table to decrease even further, possibly killing off riparian vegetation and increasing erosion (Brunke and Gonser, 1997; de Rosnay and Polcher, 1998).

This study examines groundwater/surface water interactions, and uses changes in the distribution of phreatophytes to quantify hydrologic pathways and controls. Remote sensing software was used to digitize tree locations, and GIS tools were used to relate tree location with soil type, depth to water, and distance to rivers. While several studies used remote sensing approaches to investigate groundwater (Ahmad et al., 2005; Becker, 2006; Jiang et al., 2008; Münch and Conrad, 2007; Rodell et al., 2007), none specifically emphasized phreatophyte distribution. The specific need to incorporate groundwater root uptake with remote sensing techniques was articulated by Winsemius et al. (2008). This study addresses the question: "Can we use changes in tree distribution to infer good recharge zones, which are needed to fill the aquifer?".

\section{Methods}

The distribution of phreatophytes that tap groundwater is closely related to the depth to water since trees have limited capacity to uptake groundwater as depth increases. The depth to water is obtained in ArcGIS by subtracting a $30 \mathrm{~m}$ digital elevation model (DEM) from groundwater elevation. This was accomplished using groundwater elevation at observation wells in Kansas available through the Water Information Storage and Retrieval Database (WIZARD); this dataset was used by McGuire (2011) to map water level changes in the High Plains. A raster map of water level was obtained by kriging the elevation from wells in southwestern Kansas. These wells represent all WIZARD wells that were measured during the recovery period after the cones of depression have recovered from yearly irrigation and before winter pre-irrigation for the next year occurs (Steward et al., 2009). Fluctuations in water level elevation caused by barometric pressure on the order of fractions of meters (Butler Jr. et al., 2011) were not specifically addressed, since the drawdown 

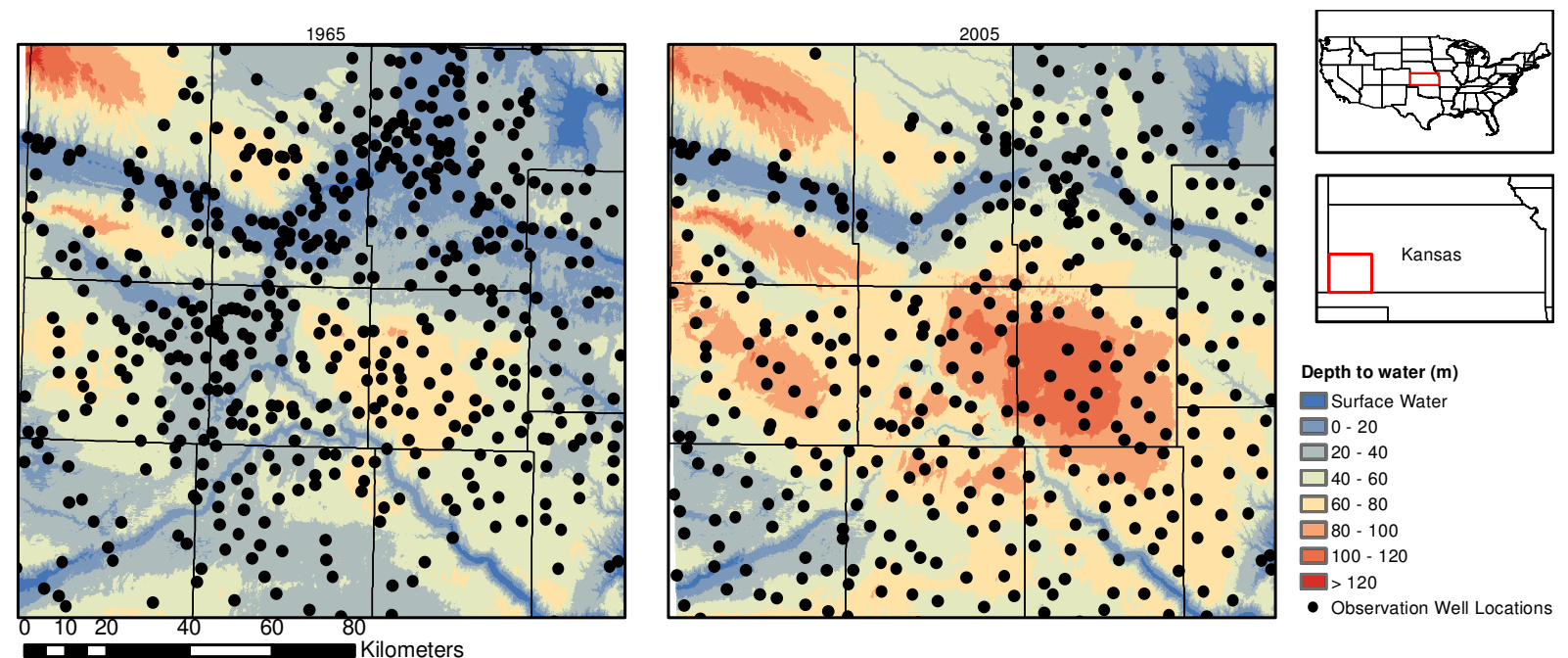

Depth to water (m)

Surface Water

$\square 0$ - 20

$\square 20-40$

$\square 40-60$

$\square 60-80$
$\square 80-100$

$\square 100-120$

- Observation Well Locations

Fig. 1. The study region in southwestern Kansas and depth to water in 1965 and 2005, years for which aerial photography is available.

created by pumping over the $40 \mathrm{yr}$ study period is on the order of 10 s of meters. The raster calculator in ArcGIS was used to create a depth to water raster by subtracting the water table elevation from the surface elevation provided by the DEM. The resulting depth to water maps are illustrated in Fig. 1 for 1965 and 2005. These years are important as they represent pre-development conditions before considerable well development and more recent post-development conditions. They also represent dates for which digital imagery is available. Note that depth to water is shallow along the Arkansas River corridor in the northern portion of these figures and along the Cimarron River corridor in the southern portion.

The locations of trees along each of these corridors were identified using aerial photography in the vicinity of each river, as illustrated in Fig. 2. Pre-development aerial photography was taken by the USDA Commodity Stabilization Service (1957) and the USDA Agriultural Stabilization and Conservation Service $(1965,1967)$. While complete sets are not available for every year, the oldest complete set was used for each county as follows:

- Hamilton County: September 1957;

- Kearny County: July 1965;

- Finney County: August 1957;

- Morton, Stevens and Seward Counties: May 1967.

We georeferenced each pre-development aerial photograph to obtain a set of images that spanned each river corridor. Post-development photography for every county is available at the Kansas Geospatial Community Commons website. This photography was taken by the Farm Service Agency (FSA) National Agriculture Imagery Program, and is available in georeferenced MrSID format.

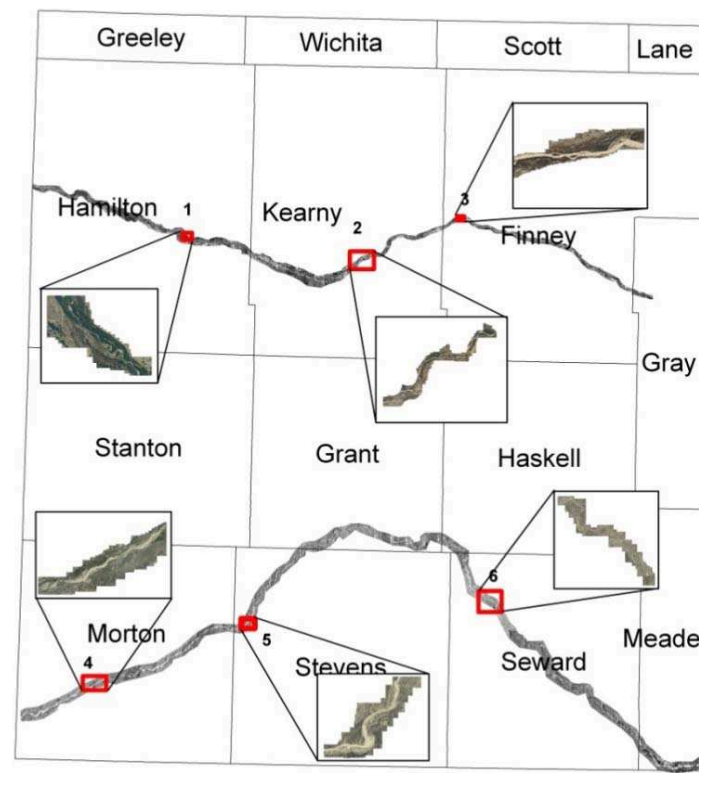

Fig. 2. The study sites and aerial photography along the Arkansas (1, 2 and 3$)$ and Cimarron (4, 5 and 6) Rivers.

Three study areas were selected in different counties along each river to test the ability of remote sensing technology to digitize tree locations. Emphasis was placed on selecting study areas displaying differences in soil type, depth to water, increase in depth to water, and tree distribution. These study areas are identified in Fig. 2. The soils data was downloaded from the Soils Data Mart created by the Soil Survey Geographic (SSURGO) Database for Hamilton, Kearny, Finney, Morton, Stevens, Gray, Haskell, Seward, and Meade Counties. 
Remote sensing software was used to create shapefiles that show tree locations in each study area. At first, an entire study area was attempted, achieving poor results. It was noted that the software accurately determined tree locations near the river, where trees were prevalent, but produced many false positives away from the river, where trees were nonexistent. To fix this problem, the photographs were clipped so that nothing beyond the boundary of the tree locations was shown.

A class hierarchy was created to classify the aerial photography for pre-development conditions. Shrub and tree classes were used to identify phreatophytes due to differences in canopy size and density. This helped to reduce the number of false positives associated with having one broad class. Classes were differentiated based on grayscale color (pre-development photos are all black and white), nearest neighbor, and homogeneity. For each class, the operator mean (arithm.) was used. The expression Gray-Level Co-Occurrence Matrix (GLCM) Homogeneity (all dir.) was added, and the expression standard nearest neighbor (generated) was also used, and the expression "similarity to class" was applied to these two classes for best results. Several samples were identified manually for each class, and then the fuzzy nearest neighbor method (Keller et al., 1985) was used to automatically classify the entire photograph based on these samples. The specific parameters used in the remote sensing software for multiresolution segmentation in the pre-development photography are shape factor 0.5 , compactness 0.5 , smoothness 0.5 , and the scale parameter is 10 (sites $1,2,5,6)$ or 20 (sites 3,4 ). A sample of the multiresolution segmentation for pre-development is shown in Fig. 3a.

The post-development photography was classified similarly to the pre-development photography. The same parameters were used for multiresolution segmentation as in the pre-development photography except that a scale parameter of 10 was used for each study site except for site 2 where 5 was used. Due to differences between study areas such as different-colored grass, varying tree thicknesses, etc., different class hierarchies were created for different study areas. Each class in all study areas used the operator mean (arithm.), and the expressions GLCM Homogeneity (all dir.) and Standard Nearest Neighbor (generated). A sample of the polygons depicting phreatophyte location for post-development conditions is shown in Fig. 3b.

Statistical analysis was conducted on the remote sensing results for each study area to determine the accuracy of the results. A sample size of 204 was chosen to be taken for each study area. This was based on the formula for the binomial probability theory:

$N=\frac{p q Z^{2}}{E^{2}}=\frac{85 \times 15 \times 2^{2}}{5^{2}}=204$

where $N$ is the sample size, $Z=2$ from the standard normal deviate of 1.96 for the $95 \%$ two-sided confidence level, $p$ is

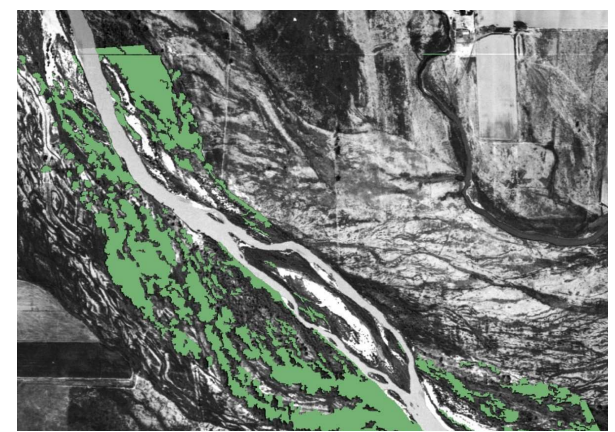

(a) Predevelopment (1965)

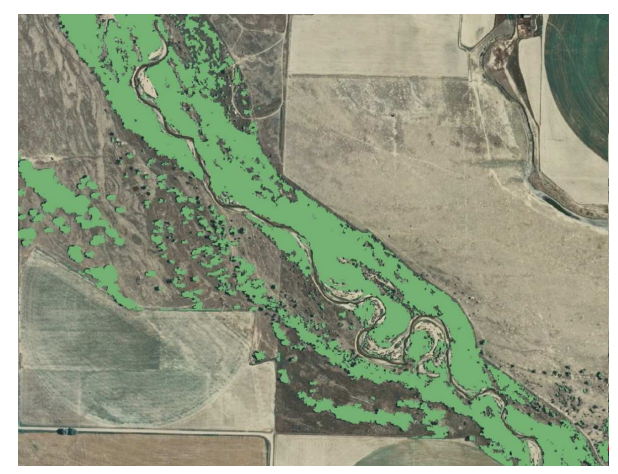

(b) Post-development (2005)

Fig. 3. An example of the multiresolution segmentation (in study site 1) used to delineate phreatophyte locations with aerial photography.

the expected percent accuracy of the entire map, $q=100-p$, and $E$ is the allowable error.

Kappa $(\hat{K})$ Analysis was used to assess the accuracy of the remote sensing results. The procedure detailed in Jensen (2005) was followed. The calculated $\hat{K}$ values showed that in most cases, moderate agreement existed between the classification map and ground reference. Tree locations were the only classification that was important, so a second error matrix was constructed combining all classifications other than trees into one field. This provided a better $\hat{K}$ result in every case.

The same techniques used to map phreatophyte locations in the study areas were used to map phreatophyte locations along the entire Arkansas River corridor from Hamilton to Finney County, and the Cimarron River corridor from Morton to Seward County. Both pre- and post-development locations were mapped, and Kappa Analysis (Jensen, 2005) was used to determine the accuracy of the results. For multiresolution segmentation, all images used a shape factor of 0.5 , compactness of 0.5 , smoothness of 0.5 , and scale parameter of 20. Ideally, the scale parameter should be lower, but due to the size of the study areas, this number could not be reduced without creating a memory error. A class hierarchy including the operator mean (arithm.) with the expressions GLCM Homogeneity (all dir.), Standard Nearest Neighbor (all dir.), 


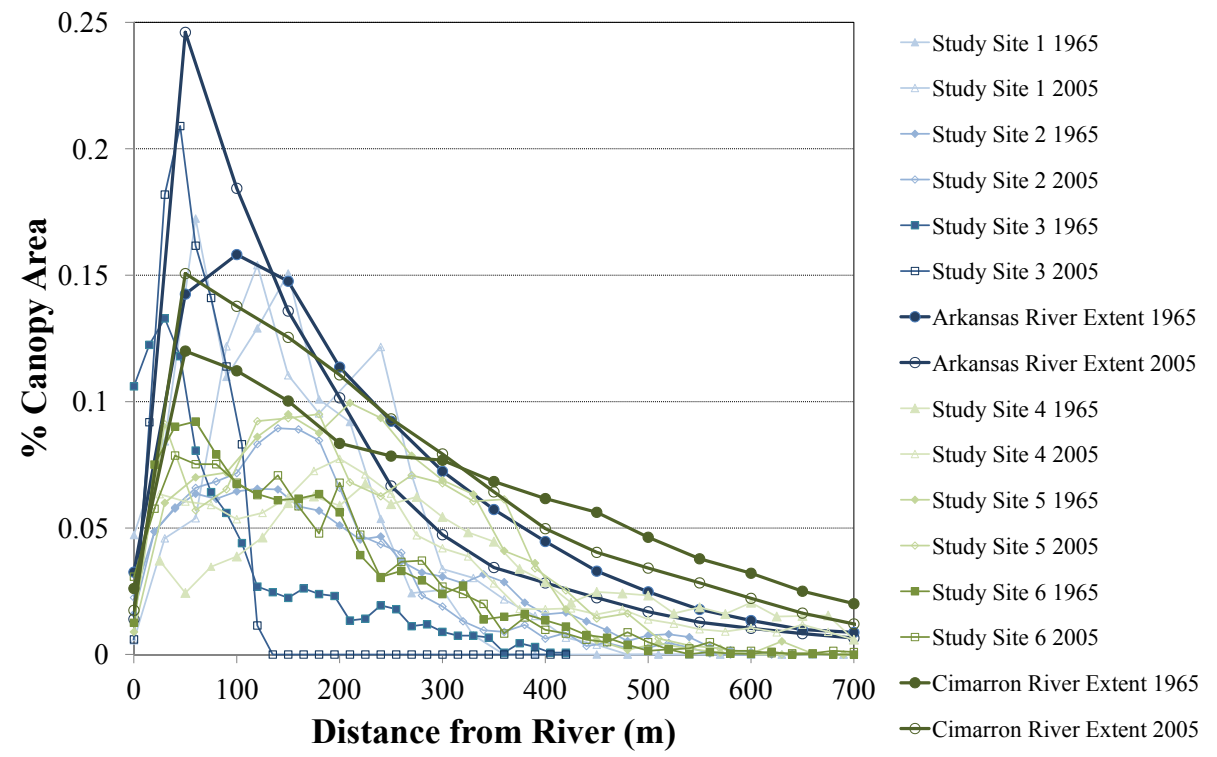

Fig. 4. The distance from phreatophytes to the stream channel in the six study sites and the river corridors.

and Shape: Area Compactness (all dir.) was created for both river corridors, pre- and post-development.

GIS software was used to create a polygon shapefile for tree locations using the remote sensing output. Shapefiles were then created that included tree locations, soils data, depth to water, change in depth to water (for postdevelopment shapefiles), and distance from a stream or river in their attribute tables. The centerline of each river was digitized for both pre-development and post-development, and the total available soil area within $700 \mathrm{~m}$ of each river was also calculated for the remote sensing results along the entire extent of the river corridors. Soil area within $620 \mathrm{~m}$ of each river was calculated at the six study sites. These distance values were chosen based on the extent of $95 \%$ confidence intervals calculated for tree distance to the river.

The statistical results presented in the next section were weighted by the area of the polygons since some polygons contained multiple trees. The weighted mean and weighted standard deviation of depth to water and change in depth to water were calculated for each case, and the weighted mean and standard deviation of distance to a stream or river were also calculated. The total areas of tree cover over hydrologic soil groups A, B, C, and D were also calculated, where these hydrologic soil groups are defined by the Soil Survey Division Staff (1993).

For class A the saturated hydraulic conductivity is very high or in the upper half of high and the internal free water occurrence is very deep; class B has saturated hydraulic conductivity in the lower half of high or in the upper half of moderately high and free water occurrence is deep or very deep; class $\mathrm{C}$ has saturated hydraulic conductivity in the lower half of moderately high or in the upper half of moderately low and internal free water occurrence is deeper than shallow; class D has saturated hydraulic conductivity below the upper half of moderately low, and/or internal free water occurrence is shallow or very shallow and transitory through permanent.

\section{Results and discussion}

The results from the remote sensing software and GIS spatial analysis enables interpretation of the hydrologic controls on phreatophyte distribution. The aggregate tree canopy along the Arkansas and Cimarron River corridors are shown in Table 1 . These results clearly illustrate a decrease in the canopy area along each river from pre-development to postdevelopment conditions.

Not only did the total area of phreatophytes decrease, but the trees also became more concentrated along the river channel. The distance from the river is plotted against a dimensionless percent of canopy area for the six study sites and the two river corridors in Fig. 4. This data shows that a higher percentage of trees were located near surface water in 2005 than in 1965. Along each river corridor, the river channel consistently decreased in overall surface area and phreatophytes became concentrated near this smaller channel as illustrated for a portion of study site 1 in Fig. 3 .

The average distance between trees and the river decreased after development along the Arkansas River corridor, but the standard deviation of distance increased, allowing for a greater range of distances in the $95 \%$ confidence interval. Based on the results from study areas 1-6, this increase in standard deviation is likely caused by the average distance to the river increasing at the far western part of the corridor, where the depth to groundwater did not decrease. This 
Table 1. The aggregate canopy area covered by phreatophytes along the Arkansas and Cimarron River corridors.

\begin{tabular}{lcc}
\hline Study area & $\begin{array}{c}\text { Pre-development } \\
\text { canopy area }\end{array}$ & $\begin{array}{c}\text { Post-development } \\
\text { canopy area }\end{array}$ \\
\hline Arkansas River & 1620 ha & 1505 ha \\
Cimarron River & 2097 ha & 1336 ha \\
\hline
\end{tabular}

contrasts with a decrease in average distance to the river along the rest of the corridor, where depth to groundwater increased. The results are then further skewed because the tree densities in the west are much greater than those in the east.

The same is true along the Cimarron River, so it is easy to presume that if Morton County were discounted, the decrease in average distance to the river would be much more profound. However, the average distance to the river increased at study sites 5 and 6 , while decreasing at study site 4 . This is the case because even though the water table has risen at study site 4 , streamflow has greatly decreased, allowing new trees to grow in areas that the river used to flow, which decreases the average distance to the river. At study sites 5 and 6 , the trees did not redistribute closer to the river because the distance to groundwater beneath the river is greater than $20 \mathrm{~m}$, so there is no significant advantage for a phreatophyte to grow there. Most of the trees that were near the river have died off, and there are almost no trees remaining. This pattern of low tree numbers in regions with large depth to groundwater is observed throughout much of the study region, and locations where phreatophytes continue to exist with large drops in groundwater elevation suggest the presence of perched conditions in the river alluvium.

The distribution of root depth to groundwater along the Arkansas and Cimarron River corridors and at the six study areas is shown in Table 2. In almost every case, trees in 2005 were located in areas with a greater depth to groundwater than in 1965. When looking at the average depth to water along the entire Arkansas and Cimarron River corridors, it appears that as depth to water increases, the number of trees decreases. However, this is not always the case, as evidenced by study site 1 (Fig. 2). As long as the water table remains at a level that is easily accessed by the roots of the trees, the trees will not die off with a decline in the water table, and the number of trees can increase. Along much of the Cimarron River corridor, the depth to groundwater has increased greatly, while along the far western part of the corridor the groundwater level increased. Most of the trees in the region where the water table has lowered have died off, so almost all of the trees along the Cimarron River corridor are clustered in the zones of shallow water table. There is an increase in average depth to water because some trees still exist at locations where the water table is very deep, and many new trees are located in areas that have experienced increases in groundwater
Table 2. Weighed mean and standard deviation for depth to water beneath phreatophytes.

\begin{tabular}{lrrrrr}
\hline & \multicolumn{2}{c}{ Pre-development } & & \multicolumn{2}{c}{ Post-development } \\
\cline { 2 - 3 } \cline { 5 - 6 } Study area & Mean & $\begin{array}{c}\text { Standard } \\
\text { deviation }\end{array}$ & & Mean & $\begin{array}{r}\text { Standard } \\
\text { deviation }\end{array}$ \\
\hline 1 & $1.4 \mathrm{~m}$ & $0.8 \mathrm{~m}$ & & $2.1 \mathrm{~m}$ & $1.0 \mathrm{~m}$ \\
2 & $1.1 \mathrm{~m}$ & $0.9 \mathrm{~m}$ & & $12 \mathrm{~m}$ & $1.1 \mathrm{~m}$ \\
3 & $1.0 \mathrm{~m}$ & $0.5 \mathrm{~m}$ & & $19 \mathrm{~m}$ & $0.3 \mathrm{~m}$ \\
Arkansas River & $1.6 \mathrm{~m}$ & $1.4 \mathrm{~m}$ & & $6.0 \mathrm{~m}$ & $6.3 \mathrm{~m}$ \\
4 & $0.9 \mathrm{~m}$ & $1.2 \mathrm{~m}$ & & $0.2 \mathrm{~m}$ & $0.6 \mathrm{~m}$ \\
5 & $11 \mathrm{~m}$ & $2.1 \mathrm{~m}$ & & $21 \mathrm{~m}$ & $2.6 \mathrm{~m}$ \\
6 & $7.1 \mathrm{~m}$ & $2.2 \mathrm{~m}$ & & $28 \mathrm{~m}$ & $3.3 \mathrm{~m}$ \\
Cimarron River & $3.5 \mathrm{~m}$ & $4.9 \mathrm{~m}$ & & $8.8 \mathrm{~m}$ & $14 \mathrm{~m}$ \\
\hline
\end{tabular}

level, but have a depth to water that is greater than what was beneath the entire Cimarron River prior to development.

Canadell et al. (1996) found the maximum rooting depth of cottonwood trees in a forest to be $2.6 \mathrm{~m}$. The average depth to water beneath tree canopy at study site 1 is less than $2.6 \mathrm{~m}$ both prior to and post-development, so it seems that $2.6 \mathrm{~m}$ is probably close to the threshold where cottonwoods will start to die off with an increase in depth to water. This die-off trend is certainly not linear, and the introduction of tamarisk further complicates the prediction of tree die-off because studies have shown that water table depths have little to no effect on tamarisk, even at depths below $10 \mathrm{~m}$ (Cleverly et al., 2006). In our study area, it was also found that areas with a dense tree population ( $>10 \%$ tree cover) occurred where the average depth to water ranged from $0.24-1.4 \mathrm{~m}$. Areas with moderate tree density (5-10\% tree cover) corresponded to an average depth to water ranging from $2.1-19 \mathrm{~m}$. Areas with a low tree density ( $<5 \%$ tree cover) corresponded to an average depth to water ranging from 11-28 $\mathrm{m}$ (Ahring, 2009).

The areas of each hydrologic soil group were calculated within $700 \mathrm{~m}$ of the rivers in each study area as shown in Table 3. This table also shows the pre-and post-development percentage of land area under tree canopy for each study area. Expected tree canopy areas were calculated by assigning an equal percentage of total tree canopy area to each soil type, based upon the percentage of the soil type located within the study area. More trees were located on hydrologic soil group A than would be expected if tree location were independent of soil type in every case, and less trees were located on soil group B. In some cases, trees were more likely to be on soil groups $\mathrm{C}$ and $\mathrm{D}$ than expected, and in other cases, fewer trees were on those soils than expected. However, trees along both the Cimarron and Arkansas Rivers were more likely to be located on soil group D post-development than during pre-development. It is not apparent what would cause this shift to soil group D because it has a low hydraulic conductivity, but one could speculate that this soil group might be more conducive to tamarisk, which has increased in 
Table 3. The percent of phreatophyte canopy area over soil classes in pre-development and post-development times.

\begin{tabular}{|c|c|c|c|c|c|c|c|c|c|c|c|c|c|c|c|}
\hline \multirow[b]{2}{*}{ Study area } & \multicolumn{3}{|c|}{ Soil Group A } & \multicolumn{3}{|c|}{ Soil Group B } & \multicolumn{3}{|c|}{ Soil Group C } & \multicolumn{3}{|c|}{ Soil Group D } & \multicolumn{3}{|c|}{ Aggregate } \\
\hline & 1965 & 2005 & Area & 1965 & 2005 & Area & 1965 & 2005 & Area & 1965 & 2005 & Area & 1965 & 2005 & Area \\
\hline 1 & 1.4 & 1.1 & 8.9 & 0.0 & 0.0 & 0.4 & 11.2 & 12.7 & 69.6 & 0.4 & 3.0 & 21.1 & 12.9 & 16.7 & 100.0 \\
\hline 2 & 3.4 & 1.9 & 31.1 & 0.0 & 0.0 & 6.7 & 2.4 & 1.6 & 51.9 & 0.3 & 0.0 & 10.4 & 6.1 & 3.5 & 100.0 \\
\hline 3 & 4.7 & 0.0 & 16.0 & 0.0 & 0.0 & 2.7 & 10.3 & 7.7 & 56.6 & 0.0 & 0.0 & 24.7 & 15.0 & 7.7 & 100.0 \\
\hline Arkansas River & 2.8 & 3.4 & 20.0 & 0.2 & 0.4 & 14.0 & 3.2 & 2.4 & 50.0 & 0.9 & 1.2 & 16.0 & 7.0 & 7.4 & 100.0 \\
\hline 4 & 6.2 & 8.5 & 57.7 & 0.5 & 0.7 & 42.3 & 0.0 & 0.0 & 0.0 & 0.0 & 0.0 & 0.0 & 6.6 & 9.2 & 100.0 \\
\hline 5 & 1.8 & 1.0 & 99.9 & 0.0 & 0.0 & 0.1 & 0.0 & 0.0 & 0.0 & 0.0 & 0.0 & 0.0 & 1.8 & 1.0 & 100.0 \\
\hline 6 & 2.5 & 0.7 & 64.7 & 0.4 & 0.4 & 34.7 & 0.0 & 0.0 & 0.6 & 0.0 & 0.0 & 0.0 & 3.0 & 1.2 & 100.0 \\
\hline Cimarron River & 4.5 & 3.1 & 51.6 & 1.2 & 0.7 & 40.7 & 0.5 & 0.2 & 3.5 & 0.3 & 0.2 & 4.2 & 6.6 & 4.2 & 100.0 \\
\hline
\end{tabular}

population since development and relies largely on groundwater sources (Busch et al., 1992). It should be noted that the canopy area along the Arkansas River shows an increase from 7.0 to $7.4 \%$ of the aggregate area over hydrologic soil groups $\mathrm{A}, \mathrm{B}, \mathrm{C}$ and $\mathrm{D}$, while Table 1 shows a decrease along this river. This is because many of the pre-development trees were located on classes other than these soil groups (e.g. some were located in the river).

Phreatophyte distributions can be used as indicators for soil type, hydraulic connectivity, and depth to groundwater. In Western Kansas, areas with good hydraulic connectivity are of interest because it is not economically feasible to create artificial recharge projects that use injection due to treatment costs. This is the unfortunate case, since rivers in the study region flow seldom if at all, and excess discharge above authorized surface water rights does not exist as it does further east near Wichita, Kansas, where Aquifer Storage and Recovery is filling the Equus Beds Aquifer for the city's municipal and industrial needs. It would be feasible, however, to route ditches over land with good hydraulic connectivity to increase natural recharge. It is possible that phreatophyte locations could be used to indicate locations with good surface water/groundwater connectivity because of the likelihood of phreatophytes to be located on hydrologic soil group A. It was found here that phreatophytes exist on all hydrologic soil types, so enhanced areas of recharge must take into account more than just the surficial soils.

Phreatophyte distributions are a good indicator of depth to groundwater since a dense distribution of trees indicates a shallow water table, while a sparse distribution indicates a deep water table. The distribution of phreatophytes may also be influenced by human activity (tree cutting) and climatic conditions (flooding events); however, the occurrence of dead tree stands, interpretation of USGS gauging station data, and anecdotal evidence from conversations with local stakeholders suggests that such forcings have not significantly impacted phreatophyte distribution in the study region. Figure 5 identifies areas of high recharge by quantifying the decrease or increase in phreatophyte canopy area and changes in the depth to groundwater from pre- to post-development. This figure was constructed by centering

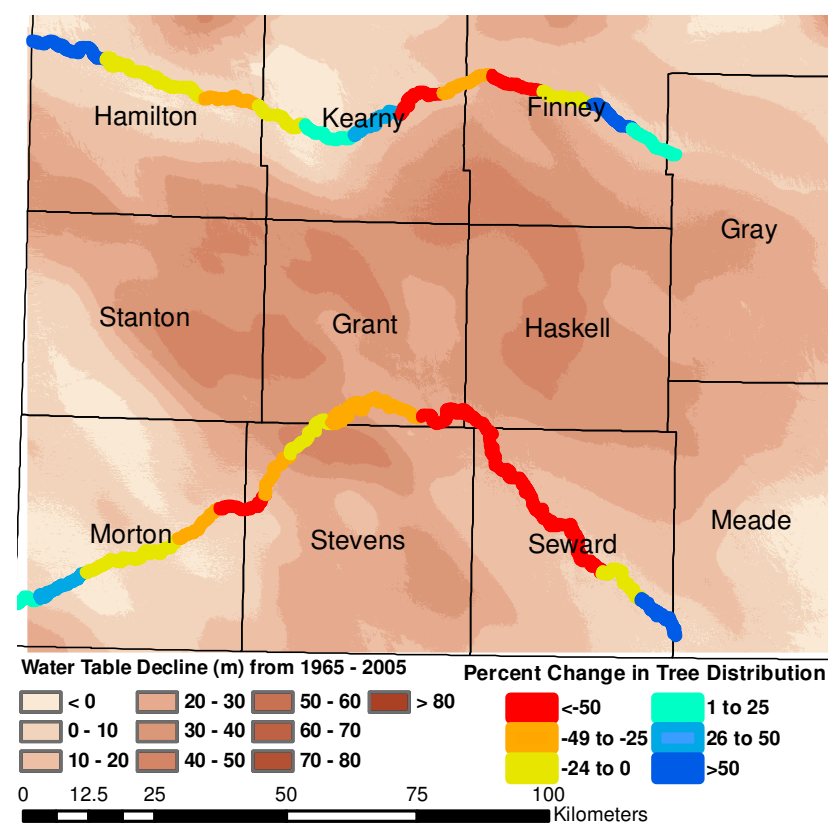

Fig. 5. The decrease (red) or increase (blue) in phreatophyte canopy area between pre-development and post-development correlates with changes in the depth to groundwater, and substantiates the occurrence of high recharge zones.

circles with $5 \mathrm{~km}$ radii along each river and computing the change in canopy area over each river segment. The mean change in groundwater elevation is tabulated for each class of percent change in canopy in Table 4.

Along the Arkansas River, pre-development phreatophytes generally existed along a river corridor with mean depth to water of $1.5 \mathrm{~m}$ or less. In general, phreatophyte concentrations decreased substantially along river segments where the depth to water decreased by more than $8 \mathrm{~m}$, with an exception in the central portion of Kearny County.

The phreatophyte distribution along the Cimarron River shows the same patterns of increase in canopy area to the west and east and decreases in the central portion of the study region. Phreatophytes increased in areas where groundwater remains within $1 \mathrm{~m}$ of land surface (note that negative values 
Table 4. The mean pre- and post-development groundwater elevation and the change in groundwater elevation are tabulated for each class of $\%$ change in canopy area. Negative values indicate higher groundwater than river elevation, and that baseflow conditions exist from groundwater to surface water.

\begin{tabular}{lrrrrrrrr}
\hline \multicolumn{8}{c}{ Mean groundwater elevation $(\mathrm{m})$} \\
\hline Canopy & \multicolumn{3}{c}{ Arkansas River } & & \multicolumn{3}{c}{ Cimarron River } \\
\cline { 2 - 3 } \cline { 7 - 9 } change & 1965 & 2005 & Change & & 1965 & 2005 & Change \\
\hline$<-50 \%$ & 0.3 & 16.6 & 16.4 & & 7.3 & 24.8 & 17.5 \\
$-50--25 \%$ & -0.1 & 8.7 & 8.8 & & 8.1 & 30.0 & 21.9 \\
$-25-0 \%$ & 1.0 & 5.8 & 4.8 & & 1.2 & 13.6 & 12.4 \\
$0-25 \%$ & 1.3 & 6.8 & 5.5 & & -9.8 & -1.0 & 8.8 \\
$25-50 \%$ & 1.5 & 11.4 & 9.9 & & -6.4 & -4.4 & 2.0 \\
$>50 \%$ & 0.2 & 3.9 & 3.7 & & -9.1 & -4.5 & 4.6 \\
\hline
\end{tabular}

of depth to water indicate that groundwater is providing baseflow to rivers). Phreatophytes decrease along the Cimarron River where depth to water and change in groundwater elevation both fell below $10 \mathrm{~m}$.

Phreatophyte distribution is influenced by the occurrence of streamflow. Along the Arkansas River, streamflow exists in the western portion of the study area. Peak streamflows in Kansas are now limited by reservoirs in Colorado, yet the Arkansas River compact legally requires annual streamflow releases from Colorado to Kansas. While the Arkansas River is one of three publicly accessible rivers in Kansas, there has been no measurable streamflow in the eastern portions of the study region in many recent years. One reason for this is the Bear Creek fault in Kearny County that serves as a conduit for surface water to drain from the Arkansas River to the Ogallala, and this along with unlined diversion ditches may reduce streamflow. Gauging stations along the Cimarron indicate that the river flows into Kansas and out of Kansas but the river largely disappears throughout the central portion of the study region.

It stands to reason that in areas where there is no regular stream flow, tree locations could be used to indicate levels with high potential for recharge. The Ogallala Aquifer was too deep to support phreatophytes in pre-development conditions and trees were located within river corridors. Along much of the central portions of each river corridor, the declining groundwater tables have fallen below published depths to which Kansas phreatophyte species are capable of surviving. In areas where there is large post-development depth to water and little to no streamflow, the presence of phreatophytes may indicate an alluvial aquifer with perched conditions and an underlying aquitard that keeps ephemeral surface water from moving directly downward into the Ogallala Aquifer. Such alluvium exists along portions of the Arkansas River corridor including Kearny County (Yang, 2012). Areas with no trees do not have an alluvial aquifer and have high recharge potential.

\section{Conclusions}

The Ogallala Aquifer has been pumped for irrigation in Kansas since the 1950's. Since this time, some regions of Western Kansas have experienced a water table decline of more than $40 \mathrm{~m}$ (Fig. 1). The decline of the water table, as well as a change in overall land use, has caused a redistribution of riparian phreatophytes along the Cimarron and Arkansas Rivers. This study analyzes the redistribution of phreatophytes in Southwest Kansas to identify zones of recharge along the Arkansas and Cimarron River systems. Six study areas were chosen, and tree distributions were mapped using remote sensing on aerial photography (Fig. 2). Tree locations at each study area and also along the entire Arkansas and Cimarron River corridors were analyzed based on hydrologic soil group, depth to groundwater, increase in depth to groundwater, and distance from a stream or river.

The results for average depth to water vary spatially. In areas with a dense tree population ( $>10 \%$ tree cover), the average depth to water ranged from $0.24-1.4 \mathrm{~m}$. In areas with moderate tree density (5-10\% tree cover), the average depth to water ranged from $2.1-19 \mathrm{~m}$. In areas with low tree density ( $<5 \%$ tree cover), the average depth to water ranged from $11-28 \mathrm{~m}$. The wide ranges of values is likely due to the differences in rooting depths of cottonwood trees and salt cedars. In general, the canopy area of trees decreases as depth to groundwater increases, but phreatophytes can still exist at depths up to, and possibly exceeding, $35 \mathrm{~m}$ (in part by tapping local perched water sources in the alluvium). The results for distance to a stream or river indicate that as the water table declines, trees will be redistributed closer to the river (Fig. 4), as long as the water table near the river is shallow enough to be ideal for phreatophyte growth. Phreatophyte locations can be used as an indicator for areas with good surface water/groundwater connectivity because they are more likely to be located on hydrologic soil group A than any other group (Table 3 ). This soil group has a high hydraulic conductivity, which is one of the most important factors in determining the permeability of the hyporheic zone (Soil Survey Division Staff, 1993; Brunke and Gonser, 1997).

Phreatophyte distributions have changed over time in response to a declining groundwater table associated with pumping the Ogallala Aquifer. This study analyzed possible causes for this redistribution, and through this analysis, developed a set of conditions under which phreatophytes are likely to exist. It was shown that changes in tree distributions can be used as indicators for changes in depth to water and groundwater/surface water connectivity (Fig. 5). Large declines in canopy cover in regions with ephemeral surface water are indicative of zones with high recharge potential where surface water might be diverted to fill aquifers. These results may find particular application in other grasslands of the world with ungauged basins where changes in phreatophytes may be observed from remote sensing in locations where monitoring well networks do not exist to infer depth 
to water (Winsemius et al., 2008). This study shows that results should be interpreted through geologic understanding as faults may also provide enhanced conduits between groundwater and surface water. Future research is suggested to determine if phreatophytes are an indicator of water quality, and methods should be developed to make naturally infiltrated water cleaner without treatment. Such activities will be important to successfully filling a depleting aquifer as the existing surface water in the Arkansas River during low flow conditions contains high levels of chlorides and sulfates, and exceeds drinking water standards for uranium (Whittemore et al., 2010). Water is much cleaner during high flows, such as in the event of a flood, so a recharge project that utilized the river channel and surrounding area to capture flood flows would be highly beneficial to communities and producers along the river basin.

Acknowledgements. The authors gratefully acknowledge financial support provided by the National Science Foundation (grant GEO0909515), and the US Department of Agriculture/Agriculture Research Service (Ogallala Aquifer Project).

Special thanks to Douglas G. Goodin for use of the Remote Sensing Research Laboratory at Kansas State University, and to Andrea Brookfield and an anonymous reviewer for their insightful comments that helped to clarify contributions.

Edited by: R. P. Bartholomeus

\section{References}

Ahmad, M., Bastiaanssen, W. G. M., and Feddes, R. A.: A new technique to estimate net groundwater use across large irrigated areas by combining remote sensing and water balance approaches, Rechna Doab, Pakistan, Hydrogeol. J., 13, 653-664, 2005.

Ahring, T. S.: Phreatophytes in Southwest Kansas Used as a Tool for Predicting Hydrologic Properties, M.S. Civil Engineering, Kansas State University, Manhattan, Kansas, 2009.

Amenu, G. G. and Kumar, P.: A model for hydraulic redistribution incorporating coupled soil-root moisture transport, Hydrol. Earth Syst. Sci., 12, 55-74, doi:10.5194/hess-12-55-2008, 2008.

Becker, M. W.: Potential for satellite remote sensing of ground water, Ground Water, 44, 306-318, 2006.

Brunke, M. and Gonser, T.: The ecologycial significance of exchange processes between rivers and groundwater, Freshwater Biol., 37, 1-33, 1997.

Busch, D. E., Ingraham, N. L., and Smith, S. D.: Water uptake in woody riparian phreatophytes of the Southwestern United States: a stable isotope study, Ecol. Appl., 2, 450-459, 1992.

Butler Jr., J. J., Kluitenberg, G. J., Whittemore, D. O., Loheide II, S. P., Jin, W., Billinger, M. A., and Zhan, X.: A field investigation of phreatophyte-induced fluctuations in the water table, Water Resour. Res., 43, W02404, doi:10.1029/2005WR004627, 2007.

Butler Jr., J. J., Jin, W., Mohammed, G. A., and Reboulet, E. C.: New insights from well responses to fluctuations in barometric pressure, Ground Water, 49, 525-533, 2011.
Canadell, J., Jackson, R. B., Ehleringer, J. R., Mooney, H. A., Sala, O. E., and Schulze, E. D.: Maximum rooting depth of vegetation types at the global scale, Oecologia, 108, 583-595, 1996.

Cleverly, J. R., Dahm, C. N., Thibault, J. R., McDonnell, D. E., and Coonrod, J. E. A.: Riparian ecohydrology: Regulation of water flux from the ground to the atmosphere in the Middle Rio Grande, New Mexico, Hydrol. Process., 20, 3207-3225, doi:10.1002/hyp.6328, 2006.

Cooper, D. J., D’Amico, D. R., and Scott, M. L.: Physiological and morphological response patterns of populus deltiodes to alluvial groundwater pumping, Environ. Manage., 31, 215-226, 2003.

de Rosnay, P. and Polcher, J.: Modelling root water uptake in a complex land surface scheme coupled to a GCM, Hydrol. Earth Syst. Sci., 2, 239-255, doi:10.5194/hess-2-239-1998, 1998.

Devlin, J. F. and Sophocleous, M.: The persistence of the water budget myth and its relationship to sustainability, Hydrogeol. J., 13, 549-554, 2005.

Hoddenbach, G.: Tamarix control, in: Tamarisk Control in Southwestern United States, edited by: Kunzmann, M. R., Johnson, R. R., and Bennett, P., University of Arizona, Tucson, Arizona, 116-123, 1987.

Jensen, J. R.: Introductory Digital Image Processing: A Remote Sensing Perspective, 3rd Edn., Prentice Hall, Saddle River, New Jersey, 2005.

Jiang, Y., Zhang, C., Yuan, D., Zhange, G., and He, R.: Impact of land use change on groundwater quality in a typical karst watershed of Southwest China: a case study of the Xiaojiang watershed, Yunnan Province, Hydrogeol. J., 16, 727-735, 2008.

Keller, J. M., Gray, M. R., and Givens, J. A.: A fuzzy K-nearest neighbor algorithm, IEEE T. Syst. Man Cyb., 15, 580-585, 1985.

Law, D. J., Marlow, C. B., Mosley, J. C., Custer, S., Hook, P., and Lienard, B.: Water table dynamics and soil texture of three riparian plant communities, Northwest Sci., 74, 234-241, 2000.

McGuire, V. L.: Water-level changes in the High Plains Aquifer, predevelopment to 2009, 2007-2008, and 2008-2009, and change in water in storage, predevelopment to 2009, Scientific Investigations Report 2011-5089, US Geological Survey, Reston, Virginia, 2011.

Münch, Z. and Conrad, J.: Remote sensing and GIS based determination of groundwater dependent ecosystems in the Western Cape, South Africa, Hydrogeol. J., 15, 19-28, 2007.

Nagler, P. L., Hinojosa-Huerta, O., Glenn, E. P., GarciaHernandez, J., Romo, R., Curtis, C., Huete, A. R., and Nelson, S. G.: Regeneration of native trees in the presence of invasive saltcedar in the Colorado River Delta, Mexico, Conserv. Biol., 19, 1842-1852, 2005.

Opie, J.: Ogallala: Water for a Dry Land, 2nd Edn., University of Nebraska Press, Lincoln, 2000.

Owens, M. K. and Moore, G. W.: Saltcedar water use: realistic and unrealistic expectations, Rangeland Ecol. Manage., 60, 553-557, 2007.

Rodell, M., Chen, J., Kato, H., Famiglietti, J. S., Nigro, J., and Wilson, C. R.: Estimating groundwater storage changes in the Mississippi River basin (USA) using GRACE, Hydrogeol. J., 15, 159-166, 2007.

Shafroth, P. B., Cleverly, J. R., Dudley, T. L., Taylor, J. P., Van Riper III, C., Weeks, E. P., and Stuart, J. N.: Control of Tamarix in Western United States: implications for water salvage, wildlife use, and riparian restoration, Environ. Manage., 35, 231-246, 
doi:10.1007/s00267-004-0099-5, 2005.

Soil Survey Division Staff: Soil Survey Manual, Handbook 18, United States Department of Agriculture, http://soils.usda.gov/ technical/manual/ (last access: November 2012), 1993.

Sophocleous, M.: Groundwater recharge and sustainability in the High Plains aquifer in Kansas, USA, Hydrogeol. J., 13, 351-365, doi:10.1007/s10040-004-0385-6, 2005.

Steward, D. R. and Ahring, T.: An analytic solution for groundwater uptake by phreatophytes spanning spatial scales from plant to field to regional, J. Eng. Math., 64, 85-103, doi:10.1007/s10665008-9255-x, 2009.

Steward, D. R., Peterson, J. M., Yang, X., Bulatewicz, T., HerreraRodriquez, M., Mao, D., and Hendricks, N.: Groundwater economics: An object-oriented foundation for integrated studies of irrigated agricultural systems, Water Resour. Res., 45, W05430, doi:10.1029/2008WR007149, 2009.

Szilagyi, J., Zlotnik, V.A., Gates, J.B., and Jozsa, J.: Mapping mean annual groundwater recharge in the Nebraska Sand Hills, USA, Hydrogeol. J., 19, 1503-1513, 2011.

USDA Agriultural Stabilization and Conservation Service: Aerial photography flown by Park Aerial Surveys, Inc., Louisville, Kentucky, 1965.
USDA Agriultural Stabilization and Conservation Service: Aerial photography flown by Park Aerial Surveys, Inc., Louisville, Kentucky, 1967.

USDA Commodity Stabilization Service: Aerial photography flown by Park Aerial Surveys, Inc., Louisville, Kentucky, 1957.

West, E. and Ruark, G.: A long, long time ago ..., J. Soil Water Conserv., 59, 104A-110A, 2004.

Winsemius, H. C., Savenije, H. H. G., and Bastiaanssen, W. G. M.: Constraining model parameters on remotely sensed evaporation: justification for distribution in ungauged basins?, Hydrol. Earth Syst. Sci., 12, 1403-1413, doi:10.5194/hess-12-14032008, 2008.

Whittemore, D. O.,Petroske, E., Magnuson, M. Ahring, T. S., and Norquest, J. L.: Uranium variations and loads of the Arkansas River in the High Plains, USA, Proceedings of the Geological Society of America, Denver, Colorado, 42, p. 502, 2010.

Yang, X.: Application of the Conceptualization Groundwater Data Model to Study the Upper Arkansas River Corridor, Western Kansas, J. Earth Sci., 23, 77-87, 2012. 